\title{
The Tiananmen Square Incident of 1989
}

\author{
Zhifei Xie \\ United States \\ zhifeixie@gfs.org
}

On June 4th, 1989, the Chinese People's Liberation Army (PLA) forces brought an abrupt end to an unprecedented protest that lasted for two months at Tiananmen Square in China. The estimated death toll of the crackdown varies from several hundred to several thousand. ${ }^{1}$ While the Chinese government denied the existence of massive killing and claimed that the incident was simply a suppression of a counter-revolutionary rebellion, the foreign media characterized the event as an aggressive "massacre" that severely abused human rights. However, according to Wei Ling Chua, "Technically speaking, the nature of the protest was similar to the 2011 Wall Street protest in America. From a historical perspective, it is nothing more than another incident of mass discontent against an existing government at a time of economic hardship." ${ }^{2}$ But why did the Tiananmen Square Incident become the one that still gets mentioned even thirty years after it happened? The Tiananmen Square Incident of 1989 remains as an unforgettable event that still attracts exceptional, continuous attention from many people today. This is because of the huge difference between what the protestors sought and the violent responses that the Chinese government had on handling the demonstrations, and the exaggerated reports from the Western media who assigned China a paralyzed image.

Although the most well-known demonstration and crackdown of the Tiananmen Square Incident took place at the Square, there were protests and crackdowns all over China in 1989. Tiananmen Square is a large city square which is located in the south of Tiananmen (Gate of Heavenly Peace) in Beijing, China. The square is mainly used for gathering people for important celebrations or ceremonies. ${ }^{3}$ The Tiananmen Square protest in 1989 didn't just appear out of nowhere. From 1985 to 1989, many students and workers around the nation started to rally in support of democratic reforms. These demonstrations started as university students against the appearances of PLA soldiers in university campuses. And it was these small scale protests that eventually led to the riot at the square in 1989. ${ }^{4}$ On April 15, 1989, progressive students gathered at Tiananmen Square to grieve for Hu Yaobang's death. Hu was the former party general secretary, who was forced to resign due to his advancing liberal views and his tempered handling on the student's protest in 1986. Later on, many workers, civil servants, and others who had dissatisfaction about the Chinese government joined the students, which comprised about one million people at the square by the middle of May. ${ }^{5}$ The protests and the demonstrations soon became widespread after April 15. More than 2,800,000 students in twenty-nine provinces of China and

1. Jeff Widener, "Tiananmen Square Protests of June 1989," in Government, Politics, and Protest: Essential Primary Sources, ed. K. Lee Lerner, Brenda Wilmoth Lerner, and Adrienne Wilmoth Lerner (Detroit, MI: Gale, 2006).

2. Wei Ling Chua, Tiananmen Square "Massacre"?: The Power of Words Vs. Silent Evidence : through the Eyes of an Outcast Journalist (Scotts Valley, CA: CreateSpace Independent Publishing Platform, 2014), 2.

3. "The Tiananmen Square Protests: April 15 - June 4, 1989," in Asia and Oceania, ed. Jennifer Stock, vol. 2, Global Events: Milestone Events throughout History (Farmington Hills, MI: Gale, 2014).

4. Widener, "Tiananmen Square."

5. “The Tiananmen Square Protests: April 15 - June 4, 1989.”

www.arjonline.org

Page 1 
in eighty-four cities evolved in demonstrations. In Beijing alone, students from all divisions - those from middle and technical schools to those from colleges and universities - converged in the capital for the protest. It was truly a threat to the regime in power. ${ }^{6}$

Consider the gathering of protestors at the Square as a danger, the Chinese Communist leaders played an important role in the Tiananmen Square Incident, their decisions on reforms directly caused many Chinese to have the desire for protests. In the 1980s, the most influential and supreme head of the Chinese regime was Deng Xiaoping, who held the position of the chairman of the Central Military Commission. ${ }^{7}$ Deng Xiaoping rose to power after Mao's death. He implemented a series of reforms on economics, education, agriculture, industry, and defense, etc. Under his reforms, Chinese society became more open, and people who suffered poverty had more chances to change their lives. ${ }^{8}$ His policies such as protecting the Chinese Communist Party legitimacy with strong political controls did bring a booming age for the Chinese economy; however, they also brought nationalism and cynicism, public distrust, and wealth inequality to the Chinese public. ${ }^{9}$ Under Deng's policies, China was undertaking a transformation from a controlled economy to a more market-oriented economy, which resulted in a rising cost of living, unemployment, and corruptions. These feelings of bitterness in life eventually led to the desire for protest and reform and ignited the protest of $1989 .{ }^{10}$ But the protest and reform could not exist if society forbade people to accept new ideas.

During the 1980s, the Chinese lived in a more liberal society where new ideas were highly accepted, and the generation who grew up in this age had increasing faith in reforms. The 1980s was the post-Mao era in China. The post-Mao leadership opened up the freedom to explore new spaces. The writers, artists, intellectuals, students, and professors in China sensed the opportunities to explore and express new ideas and to think and write critically. ${ }^{11}$ Under this free environment, the intellectuals not only seek for better material lives, but they also wanted higher respect of individualism and more political rights. ${ }^{12}$ From an age standpoint, the university student protestors of the 1989 incident were about eighteen to twenty years old when the protest began, so most of them were born during the early 1970s. Thus, they were the generation who grew up with the rapid development of novel ideas. Being deeply influenced by individualism, they considered choosing one's belief and pursuing one's goal as a right. Hence, the protestors who lived in the open society were remarkably determined and zealous on the success of reforms, which made the collapse of the protest even more memorable for them.

Although the intellectuals saw the developments of liberalism in China, Deng's policies started to worry them, which indirectly caused the students to start the protest with the goal of expressing their political opinions. At first, the students and intellectuals were enthusiastic about Deng's reforms and opening policies, but later on, they started to worry that the reforms were only focusing on economics, and the university students started to worry about their future and the government's treatment to intellectuals. ${ }^{13}$ Besides an uncertain future, many other social issues started to surface. Corruption and nepotism of some officials and harsh material life that was caused by inflation infuriated not only the intellectuals but also the majority of the Chinese working class. ${ }^{14}$

6. Peter Li, Steven Mark, and Marjorie H. Li, Culture and Politics, China: An Anatomy of Tiananmen Square (Piscataway, N.J.: Transaction Publishers, 2007), 1.

7. Xiaoqing He, "The 1989 Tiananmen Movement and Its Aftermath," Oxford Research Encyclopedias, last modified December 2017, accessed April 8, 2019.

8. "The Tiananmen Square Protests: April 15 - June 4, 1989".

9. He, “The 1989," Oxford Research Encyclopedias.

10. Chua, Tiananmen Square, 2.

11. He, "The 1989," Oxford Research Encyclopedias.

12. He, "The 1989," Oxford Research Encyclopedias.

13. He, "The 1989," Oxford Research Encyclopedias.

14. Kate Merkel-Hess, Kenneth Pomeranz, and Jeffrey Wasserstrom, eds., China in 2008: A Year of Great Significance (Lanham, Md. [u.a.]: Rowman \& Littlefield Publ., 2009), 137.

American Research Journal of History and Culture

Page 2 
Under this circumstance, many Chinese wanted capable government leaders who truly understood people's needs and took action to make changes. Hu Yaobang, the party general secretary, was forced to resign due to his advancing liberal views and his tempered handling of the student's protest in 1986, and on April 15, 1989, this great leader who was sympathetic to the average people died..$^{15}$ For the reformists, $\mathrm{Hu}$, who was like the only saver of China, passed away, so their future became vague again. On the same day of Hu's death, progressive students gathered at the Tiananmen Square to grieve for $\mathrm{Hu}$, but most of the students emphasized that they were neither against the country nor the party. They just wanted an equipotent talk(dialogue) with the government on the subject of their wishes for free speech, free press, and an end to inflation and government corruption. ${ }^{16}$ When it was the early stage of the protest, the student protestors did not proceed with any aggressive action against the government and they explained their intentions clearly. Also, the government did not treat the protestors from the past harshly. Therefore, it is reasonable to assume that the majority of the protestors at the Square did not foresee that the government would use forces to violently cease the protest two months later, and they still firmly believed that the Chinese government would offer a satisfying answer regarding their requests under the pressure from large demonstrations. Therefore, the crackdown on June 4 almost happened in everyone's surprise, which made the fatal death at the Square even more unforgettable.

While the protestors claimed that they were not against the state nor the party, the Chinese government recognized them as a hazard to the regime, which provoked all the protestors and pushed the protest to be more radical. "On April 26, People's Daily editorial labeled the student movement 'turmoil'," said Louisa Lim. ${ }^{17}$ The students and other protestors were enraged and humiliated because they considered the protest as a way of obtaining the rights that they deserved, but not a tumult that eroded the Chinese Communist party and society. Therefore, the protestors, especially the students, taking the government's outrageous response as their reason, started a 3000 people hunger strike at Tiananmen Square on May 13 that lasted for seven days. ${ }^{18}$ By this point, most of the protestors realized that it was impossible to receive a favorable response from the government on the subject of reforms. And the growing number of new participants for the demonstrations heightened the spirit of the protest that the protestors advanced their requests even more radically. On May 29, the protestors who gathered at the square erected the large statue of the "Goddess of Democracy". ${ }^{19}$ Then, they issued several documents to claim their principles of the protest and their rights, which included a Declaration of Human Rights. According to the Declaration of Human Right, the second principle stated that "the rights to life and security, and to oppose oppression, are humankind's inalienable natural rights." And the fourteenth stated that "the army is the defender of the interests of the people and of the state. It must strictly observe neutrality in political affairs and not (be subordinate to) an individual or a political party." ${ }^{20}$ It was clear that the determination of protestors was unflinching, and they believed that justice was on their side. Therefore, the crackdown of the government literally desecrated the protestors' belief in justice and human rights, which kept the protestors who lived through the crackdown from forgetting the tragic incident.

The other factor that encouraged the protestors to make devotion on supporting democracy might be the fall of Communism in Eastern Europe and the appearance of western media at Tiananmen Square. In 1989, Communism failed abruptly in Eastern Europe. According to John Merriman, "The fall of Communism took ten

15. "The Tiananmen Square Protests: April 15 - June 4, 1989".

16. He, "The 1989," Oxford Research Encyclopedias.

17. Louisa Lim, The People's Republic of Amnesia: Tiananmen Revisited (New York: Oxford University Press, 2015) Timeline.

18. He, "The 1989," Oxford Research Encyclopedias.

19. "Tiananmen Square Declaration of Human Rights," in Human and Civil Rights: Essential Primary Sources, ed. Adrienne Wilmoth Lerner, Brenda Wilmoth Lerner, and K. Lee Lerner (Detroit, MI: Gale, 2006).

20. "Tiananmen Square Declaration of Human Rights."

American Research Journal of History and Culture

Page 3 
years in Poland, ten months in Hungary, ten weeks in East Germany, ten days in Czechoslovakia, and ten hours in Romania." ${ }^{21}$ Moreover, the presence of western media at Tiananmen Square convinced the protestors that the world was watching them closely, which acted as a western approval that intensified the students' confidence even more. ${ }^{22}$ The student leaders were "convinced that the presence of a large international press corps here to cover the visit of Soviet President Mikhail Gorbachev helped to restore order, whatever the cost," reported by the Washington Post. ${ }^{23}$ By believing "the world is watching us", the protestors blindly assumed that the Chinese government could not endure the pressure of fronting the rest of the world, so it was unlikely that the Chinese government would use violence to halt the demonstration. Comparing to this firm belief that no forces would be used, the destructive crackdown from the Chinese government seemed even more miserable for the Chinese. Therefore, the Tiananmen Square Incident remains as a catastrophic event in many people's memory; and whenever something related to the incident occurs, it triggers the heartbreaking memory of the incident.

On the contrary to the protestors' expectations, the Chinese government not only fired on the protestors, but it also denied all the "abuses" after the consensus of the incident went against the Communist party. Since most of the protestors were not willing to vacant the square, the Chinese People's Liberation Army (PLA) was ordered by Deng Xiaoping to clear the square with military force. On the night of June 3, 1989, into the next morning, tanks advanced and rolled through anyone and anything that blocked their way to Tiananmen Square. Many protestors were shot by guns. On June 4,1989 , the square was surrounded. ${ }^{24}$ A student protest leader, Chai Ling, described the crackdown as the following, "On the eastern and western sides of Chang'an Boulevard, blood was flowing like a river. The butchers, the soldiers of the Twenty-seven Army, pointed tanks, submachine guns, and bayonets - the effect of the tear gas already had worn off - at those people who dared to yell out even one slogan." ${ }^{25}$ Although the credibility of this narrative is doubtable, and the description seems overly exaggerated, but it witnessed the Chinese government using violence to eliminate anyone who disobeyed the Communist regime. The act of commanding military troops to shoot the unarmed citizens completely despoiled the protestors' belief that it is a right to oppose oppression and the belief that the army should only protect the people's interests. Although the upheaval was concluded by the Chinese government winning the stalemate, the casualties were severe. Estimates varied from several hundred to thousands of death. Most of the leaders of the protest were soon arrested, imprisoned, or even executed. ${ }^{26}$ And yet, The official narrative of the government claimed that the military crackdown prevented the riot which endangered the stability and prosperity of the country. And the official justification named the protestors as "counter-revolutionaries". ${ }^{27}$ After all of these, the protestors who were still alive finally understood that a freer environment, the world's attention, democracy, better material lives, and people's rights were all foolish jokes in front of their supreme government. Their struggles with corruption and harsh lives and their efforts for a greater future were concluded as a disorder that threatened the stability and prosperity of their country by their government. The protestors who perceived themselves as the fearless warriors who were willing to stand up for reforms were depicted as "counterrevolutionaries". Therefore, it is reasonable that the protestors who survived from the crackdown engraved this depressing and humiliating memory of the Tiananmen Square Incident in their hearts and spread their encounters at the Square to the world whenever they could.

21. John M. Merriman, A History of Modern Europe: From the French Revolution to the Present, 2nd ed. (New York: W.W. Norton, 2004), 1306.

22. Li, Mark, and Li, Culture and Politics, 270.

23. Li, Mark, and Li, Culture and Politics, 270.

24. "The Tiananmen Square Protests: April - June 4, 1989".

25. He, "The 1989," Oxford Research Encyclopedias.

26. "The Tiananmen Square Protests: April 15 - June 4, 1989".

27. He, “The 1989," Oxford Research Encyclopedias.

American Research Journal of History and Culture 
While the discontentment of the Chinese public started to become unmanageable, the Chinese government took swift actions to prohibit any progressive comments on the incident. Immediately after the crackdown, the propaganda officers of the People's Liberation Army took control of all media in Beijing. Many reporters and the director of the People's Daily were dismissed from their posts because of their sympathy towards the protestors. The World Economic Herald, a liberal newspaper in Shanghai was shut down. ${ }^{28}$ Controlled media portrayed the protestors as aggressors and reactionaries, and the incident became a taboo topic anywhere in the public till today. ${ }^{29}$ In order to prevent future demonstration, political education about Chinese Communism became a required part of students' education. According to Jeff Widener, "Many schools adopted a statewritten curriculum which focuses on China's achievements and the excesses of the West." ${ }^{\prime 30}$ Therefore, the average Chinese people were not only horrified by seeing the scene of the Chinese government shooting at their compatriots, but were also afraid that their hope for freedom and an opened state had also failed. Before the crackdown, many Chinese were convinced that a flourishing future was within touch because of the Tiananmen Square protest, but the military forces aggressively demolished this dream into pieces overnight. Furthermore, the freedom of speech was limited by the government, and once again the government became the one who regulated the media. ${ }^{31}$ Consequently, the Tiananmen Square Incident became the turning point where the Chinese who used to believe in changes began to lose their faith in the Communist government. Therefore, whenever there are rumors relating to human rights abuses that are happening in China today, many Chinese would still make a reference on the Tiananmen Square Incident and even take about how the incident of June 4 may happen again privately with one another.

Besides the discrepancy between the reformers' wills and the government's crackdown that facilitated more public awareness inside China, the overstated reports of the Western media and Western countries' reactions stimulated the continuous "popularity" of the Tiananmen Square Incident in the world. Immediately after the event, the U.S. and the European Nations went into an agreement of condemning China for the incident on June 4,1989 . Collectively, they imposed several sanctions, "such as suspension of high-level official contact, a freeze on military cooperation, an embargo on the arms trade, and postponement of new requests to the World Bank," said XueYing $\mathrm{Hu}^{32}$ Without a doubt, the condemnations and sanctions from the U.S. and the European Nations were telling the rest of the world that China was standing at the opposite front against them, and whoever was supporting China would be their "foe". This is why the reports and public opinions from the rest of the world became one-sided after the U.S. and the European nations responded to the incident. With this single-sided perspective, the world would always refer to the Tiananmen Square Incident as an epitome of human rights abuses.

The western statements about the incident were completely different from the Chinese accounts. After the incident, the Chinese government had always held the proposition that nobody was killed in the incident; however, the Western media insisted that the Chinese government was hiding the truth of the massacre at the Square. ${ }^{33}$ It is undoubted that the Chinese answer for the incident was highly biased, but the trustworthiness of the western media when addressing the Tiananmen Square Incident was questionable too. Most of the Western media seemed using words like "Massacre" intentionally in their reports. ${ }^{34}$ Some of them turned the

28. Li, Mark, and Li, Culture and Politics, 273.

29. "The Tiananmen Square Protests: April 15 - June 4, 1989".

30. Widener, "Tiananmen Square."

31. "The Tiananmen Square Protests: April 15â€"June 4, 1989.

32. XueYing Hu, "Legacy of Tiananmen Square Incident in Sino-US Relations (post-2000)," East Asia: An International Quarterly 33, no. 3 (September 2016).

33. Chua, Tiananmen Square, 10.

34. Chua, Tiananmen Square, 13-14.

American Research Journal of History and Culture 
1989 incident that was mainly seeking economic reform to serious exploitation of human rights without even mention the economic hardship in China. ${ }^{35}$ Besides the selective language in the reports, some exaggerated descriptions were contradicted to the pictured evidence. Despite words like "massacre", "violently", "crushing", and "firing" appeared in a high frequency in western media narrations, there was no evidence of "mass killing" from the picture evidence provided by The Atlantic on 4 June $2012 .{ }^{36}$ Instead of the depiction of unarmed and peaceful protestors by the Western media, the picture evidence from The Atlantic (4 June 2012) titled 'Tiananmen Square, Then and Now' presented the aggression and violence of the protestors ${ }^{37}$ Hence, whether the western media were reporting the truth of the Tiananmen Square Incident or they were simply portraying an image of China with selective approaches and topics is very arguable. ${ }^{38}$ Therefore, it is reliable to assume that the western media were being selective when reporting the incident in order to embed a negative memory of China into people's head. When particular languages and topics of the incident were repeated enough times, it became laborious for people to disremember the miserable Tiananmen Square Incident and the wicked Communist government.

From the beginning of the protest to the end, the Western media chiefly dedicated its efforts on describing the brutal crackdown and criticizing the Chinese Communist government. Before the incident, the major coverage of China in the foreign media was no more than communism and troubles in the economy during the years of 1986-1987..$^{39}$ It is thus clearly evidenced that the Western media mainly targeted China on its Communist regime for defending the interests of the capitalist states, so it would be pretty likely that the Western media made a big fuss on how Communism infringed human rights when the crackdown at the Square happened. The highlights of the Western reports back in 1989 were chiefly the statue of the "Goddess of Democracy" and "the defiant student standing in front of a column of tanks". ${ }^{40}$ These highlights "support a clear dichotomy between good and evil, freedom and repression, democracy and dictatorship," which portrayed a significantly wicked image for the Chinese government. ${ }^{41}$ Moreover, at the beginning of the incident, the foreign media only gave a cursory mention about Hu Yaobang's death and the fact that students' demonstrations were started with memorizing Hu Yaobang. And certainly, the mourning was not considered to be qualified as front-page news. ${ }^{42}$ However, when an event starts to have a level of violence, it then becomes "newsworthy" to be covered on the frontpage. So after the crackdown, most of the media soon devoted their coverage to the dramatic demonstrations and the government's ill-responses. ${ }^{43}$ By narrating extreme words, the Western media manipulate the public to have an awful impression and even hatred towards the targeted government. ${ }^{44}$ Therefore, it is confirmed that the Western media only reported particular parts of the incident that were considered to be beneficent to their interests. By scrutinizing the Chinese government with propaganda, the Western nations could create a better self-image to the public. When western media repeatedly makes references on the Tiananmen Square Incident, the public will automatically perceive the Communist government as the malicious one and their own government as the fairly trustworthy one, which results in an unfaded memory of the Tiananmen Square Incident and a wicked vision of the Chinese government.

35. Chua, Tiananmen Square, 4-7.

36. Chua, Tiananmen Square, 31-36.

37. Chua, Tiananmen Square, 45-46.

38. Hu, "Legacy of Tiananmen."

39. Li, Mark, and Li, Culture and Politics, 266.

40. Chua, Tiananmen Square, 9.

41. Chua, Tiananmen Square, 9.

42. Li, Mark, and Li, Culture and Politics, 267.

43. Li, Mark, and Li, Culture and Politics, 267-268.

44. Chua, Tiananmen Square, 78-79.

American Research Journal of History and Culture 
As a result of the extreme narrations in the Western reports, the Tiananmen Square incident utterly shaped people's view of China and Chinese leaders for decades. Right after the incident, the Western media already molded the Chinese government as a wicked human right abuser. By recalling the Tiananmen Square Incident frequently when addressing Chinese new developments, the Western media draws people's attention on China and paralyzed the image of China and Communism in the public's heart. There was a peak on the number of articles related to the incident on The New York Times and The Wall Street Journal in 2001. This year, Beijing won the request of holding the 2008 Olympics. Both journals were harsh on evoking the memories of the incident, and The Wall Street Journal even described the site of bloody 1989 protests as the beginning point of Olympics. ${ }^{45}$ Between 2001-2014, The New York Times and The Wall Street Journal had issued journals that are related to the Tiananmen Square Incident on the anniversary of the event occurring every 5 years. ${ }^{46}$ It is now infrequent to see reports that only dedicated to the Tiananmen Square event; rather, the protagonists of the reports are usually current developments in China, but these developments always trigger the Tiananmen Square Incident in some ways ${ }^{47}$ For instance, when there's a report talking about democratic movements in Hong Kong, it would also make a reference on the Tiananmen Square incident to show an unchanged China. ${ }^{48}$ There is absolutely not that much significance about Tiananmen Square Incident itself for foreign countries other than China. The Western media are simply addressing the event for a continuous image of China. According to XueYing Hu, "Additionally, the persistent attention given to Tiananmen highlights the differences in policy and government (of China and other countries) and prevents China from being fully accepted into the Western community." ${ }^{\prime 4}$ Therefore, whenever there is something related to human rights developments in China, the Western media will review Tiananmen Square Incident to keep the public from forgetting the severe human rights abuses in a Communist state, which explains why the Tiananmen Square Incident remains unforgettable that it would be mentioned in the public once a while. As a result, the Tiananmen Square Incident displays a symbol of human rights abuses in China. The value of the incident itself may be faded throughout time, but the symbolic meaning of the incident remains significant to the western media. ${ }^{50}$ When referencing the Tiananmen Square incident in a report about other progress or events in China, the symbol of Tiananmen connect all these current events, which form a constant perception of China's human rights record and the Chinese government. Therefore, the exaggerated narrations from the Western media not only rose foreign awareness of the Tiananmen Square Incident and criticized a Communist state for its own benefits back in the 1980s, but they also assigned symbolic values for the incident which keeps it unforgettable today.

In conclusion, the Tiananmen Square Incident is still a popular event that draws persistent attention even in 2019. The reasons behind this "popularity" are the tremendous disparity between the positive expectation of reforms and the tragic end from the government's crackdown, and the exaggerated Western news that is determined to portray an unchanged China. Peter Li once said, "The confrontation at Tiananmen Square can be seen as a conflict between the old and the new, between the Chinese and the West, between the adherents of Deng's Four Cardinal Principles and the practitioners of bourgeois liberalism, and between the authoritarian values of the old order and the individualism of the young." ${ }^{11}$ The Tiananmen Square Incident startled everyone in the world, and it will continue to play a role in the relationship between China the rest of the world.

45. Hu, "Legacy of Tiananmen."

46. Hu, "Legacy of Tiananmen."

47. Hu, "Legacy of Tiananmen."

48. Hu, "Legacy of Tiananmen."

49. Hu, "Legacy of Tiananmen."

50. Hu, "Legacy of Tiananmen."

51. Li, Mark, and Li, Culture and Politics, 2.

American Research Journal of History and Culture 


\section{REFERENCES}

1. Chua, Wei Ling. Tiananmen Square "Massacre"?: The Power of Words Vs. Silent Evidence: through the Eyes of an Outcast Journalist. Scotts Valley, CA: Create Space Independent Publishing Platform, 2014.

This book is sort of biased. I mainly used this book to explain how the western media only used selective languages and topics when addressing the incident, and how was western media being exaggerated.

2. He, Xiaoqing. "The 1989 Tiananmen Movement and Its Aftermath." Oxford Research Encyclopedias. Last modified December 2017. Accessed April 8, 2019. http://oxfordre.com/asianhistory/view/10.1093/ acrefore/9780190277727.001.0001/acrefore-9780190277727-e-157\#acrefore-9780190277727-e-157bibliography-0003.

This resource gives me a pretty good summary of the incident from the beginning to the end. It also explains many reasons that caused the protest of 1989.

3. Hu, XueYing. "Legacy of Tiananmen Square Incident in Sino-US Relations (post-2000)." East Asia: An International Quarterly 33, no. 3 (September 2016): 213+. Accessed April 10, 2019. http://link.galegroup. com/apps/doc/A470429499/WHIC?u=garrisonfor\&sid=WHIC\&xid=91ddc4e2.

This journal helps me to find information about western reactions to the incident. It also addresses some of the protestors' reasons for starting the demonstration.

4. Li, Peter, Steven Mark, and Marjorie H. Li. Culture and Politics, China: An Anatomy of Tiananmen Square. Piscataway, N.J.: Transaction Publishers, 2007.

This book provides me general background info about the incident with details.

5. Lim, Louisa. The People's Republic of Amnesia: Tiananmen Revisited. New York: Oxford University Press, 2015.

There is a really helpful timeline of the Tiananmen Square Incident at the beginning of this book.

6. Merkel-Hess, Kate, Kenneth Pomeranz, and Jeffrey Wasserstrom, eds. China in 2008: A Year of Great Significance. Lanham, Md. [u.a.]: Rowman \& Littlefield Publ., 2009.

This book is not really helpful for my research. I just got some vague summary of the incident from the book.

7. Merriman, John M. A History of Modern Europe: From the French Revolution to the Present. 2nd ed. New York: W.W. Norton, 2004.

I used this book to explain how the fall of Communism in Eastern Europe might affect the student protestors at Tiananmen Square.

8. "Tiananmen Square Declaration of Human Rights." In Human and Civil Rights: Essential Primary Sources, edited by Adrienne Wilmoth Lerner, Brenda Wilmoth Lerner, and K. Lee Lerner, 365-67. Detroit, MI: Gale, 2006. Accessed May 1, 2019. http://link.galegroup.com/apps/doc/CX2560000135/WHIC?u=garrisonfor \&sid=WHIC\&xid=098285aa.

This resource gives me a lot of primary sources about the student protestors' declaration on human rights.

9. “The Tiananmen Square Protests: April 15â€“June 4, 1989." In Asia and Oceania, edited by Jennifer Stock. Vol. 2 of Global Events: Milestone Events throughout History. Farmington Hills, MI: Gale, 2014. Accessed May 23, 2019. http://link.galegroup.com/apps/doc/XNNNHD458570673/WHIC?u=garrisonfor\&sid=WH IC\&xid=ec8f0236. 
This is a great resource to start the research with. It provides detailed information about the causes and effects of the incident.

10. Widener, Jeff. “Tiananmen Square Protests of June 1989." In Government, Politics, and Protest: Essential Primary Sources, edited by K. Lee Lerner, Brenda Wilmoth Lerner, and Adrienne Wilmoth Lerner, 290-92. Detroit, MI: Gale, 2006. Accessed April 28, 2019. http://link.galegroup.com/apps/doc/CX2687500117/W HIC?u=garrisonfor\&sid=WHIC\&xid=0a0a4065.

I used this resource mainly for explaining the Chinese government's responses to the incident and what the government did after the crackdown.

Citation: Zhifei Xie, "The Tiananmen Square Incident of 1989". American Research Journal of History and Culture, vol 5, no. 1; pp: 1-9.

Copyright (C) 2019 Zhifei Xie. This is an open access article distributed under the Creative Commons Attribution License, which permits unrestricted use, distribution, and reproduction in any medium, provided the original work is properly cited. 